\title{
Re-examination of the previously neglected Central Asian Bucculatrix macrognathos and the consequent transfer of this species to Aristotelia, Gelechiidae, with a synonymisation of $A$. tyttha, syn. nov.
}

\author{
Oleksiy Bidzilya ${ }^{1}$, \\ Jonas R. Stonis ${ }^{2^{*}}$ \\ ${ }^{1}$ Institute of Evolutionary Ecology \\ of the National Academy \\ of Sciences of Ukraine, \\ Academician Lebedev St. 37, \\ Kyiv 03143, Ukraine \\ ${ }^{2}$ Institute of Ecology, \\ Nature Research Centre, \\ Akademijos St. 2, \\ Vilnius 08412, Lithuania
}

\begin{abstract}
Recent morphological re-examination of the previously neglected Central Asian Bucculatrix macrognathos Puplesis \& Diškus, 1996 revealed that this species actually belonged to Aristotelia Hübner, Gelechiidae and resulted in the synonymisation of another Central Asian species, A. tyttha Falkovitsh \& Bidzilya, 2003, syn. nov. The paper provides, for the first time, a photographic documentation of the male genitalia of Aristotelia macrognathos (Puplesis \& Diškus) (comb. nov.). The female genitalia are also described and illustrated for the first time.
\end{abstract}

Keywords: Atraphaxis spinosa, Bucculatricidae, male and female genitalia, new combination, new synonymy

\section{INTRODUCTION}

Aristotelia Hübner, 1825 is a genus of Gelechiidae that is characterised by a stout hook-shaped distal sclerite of the gnathos, well-developed sacculus, and the phallus often bearing short lateral thorns in the male genitalia. In female genitalia, characteristic is the ductus bursae with a patch (or patches) of minute spines. The genus has a cosmopolitan distribution: about 30 species of Aristotelia are known from the Palaearctic and 35 from the Nearctic (Lee et al., 2009); at least 50 species

\footnotetext{
* Corresponding author. Email: stonis.biotaxonomy@gmail.com
}

have been recorded in the Neotropical region (Becker, 1984) and about ten species in the Afrotropical region (Vári et al., 2002); about 20 species of Aristotelia are reported from the Oriental region and nearly 20 species from Australia (Edwards, 1996). Larvae of Aristotelia have been recorded to be feeding on Apiaceae, Ericaceae, Empetraceae, Lythraceae, Lamiaceae, Scrophulariaceae, Fabaceae, Plumbaginaceae (Bidzilya, Budashkin, 2015), and Polygonaceae (Falkovitsh, Bidzilya, 2003).

In 1996, on the basis of two specimens, $\mathrm{Pu}-$ plesis and Diškus described Bucculatrix macrognathos (Puplesis, Diškus, 1996). Both specimens were with a well-preserved, 'Bucculatricidaetype' wing pattern, but without heads. Therefore, 
neither antennasnor palpi, very important external features, were known at that time. It was expected but not proven that broken antennas might possess a scape, an enlarged first antennal segment. The male genitalia were characterized by a well-developed, distinctive gnathos. The Bucculatricidae species are usually not characterized by a gnathos, though a few species possess a gnathos and it is treated as a plesiomorphy for the family (S. V. Baryshnikova, pers. comm.). Moreover, four years earlier, B. formosa Puplesis \& Seksyaeva, 1992, another Bucculatricidae species with a well-developed gnathos was described from the same area in Kugitangtau in eastern Turkmenistan (Puplesis et al., 1992).

Due to the unexpected placement of B. macrognathos in the family Bucculatricidae, $B$. macrognathos has been left neglected and not taken into account during the description of Aristotelia tyttha Falkovitsh \& Bidzilya. The latter species was described on the basis of three males bred from Atraphaxis spinosa in the Kyzylkum Desert of Uzbekistan (Falkovitsh, Bidzilya, 2003). The larvae and the life history of A. tyttha have been described in detail (see Falkovitsh, Bidzilya, 2003).

Recently, despite the misplacement of B. macrognathos in Bucculatricidae, the first author of this article has discovered that the male genitalia of $B$. macrognathos, illustrated by Puplesis, Diškus (1996: Figs. 25, 26), fully matched those in Aristotelia Hübner, Gelechiidae. Therefore, a re-examination of the type series of $B$. macrognathos and a comparison with the most similarly looking species, A. tyttha, was proposed. Additionally, two other specimens, including previously unknown female of A. macrognathos (former A. tyttha), were found from the type locality in the Kyzylkum Desert in Uzbekistan. It has resulted in the current paper and a necessity of taxonomic changes.

\section{MATERIALS AND METHODS}

The examination and photographic documentation of the type series of the former Bucculatrix macrognathos (now transferred to Aristotelia) and Aristotelia tyttha are based on the material deposited in the collection of the Zoological Institute of the Russian Academy of Sciences, St. Petersburg, Russia (ZIN). Additional, nontype male and female specimens of $A$. tyttha are deposited in the collections of the Zoological Museum of Kyiv Taras Shevchenko National University, Kyiv, Ukraine (ZMKU).

Preparation of micro-mounts of the genital structures of the former B. macrognathos and $A$. tyttha were undertaken following the method by Stonis et al. (2014), as well as Puplesis, Diškus (2003). After maceration of the abdomen in $10 \% \mathrm{KOH}$ and subsequent cleaning, abdominal pelts were stained with Chlorazol Black (Direct Black 38/Azo Black), but male genitalia were left unstained. The genital capsules were removed from the abdomen and mounted ventral side uppermost in Euparal.

The permanent slide of the holotype of the former B. macrognathos was studied and photographed using a Leica DM2500 microscope and a Leica DFC420 digital camera. Holo-type and paratype adults were photographed using a Leica S6D stereoscopic microscope with an attached Leica DFC290 digital camera. The photographs of adults and the genitalia slides of $A$. tyttha were taken following the description by Bidzilya et al. (2017: 482).

\section{BUCCULATRIX MACROGNATHOS, A FOR- MERLY BUCCULATRICIDAE SPECIES, TRANSFERRED TO GELECHIIDAE}

Aristotelia macrognathos (Puplesis \& Diškus, 1996), comb. nov.

Bucculatrix macrognathos Puplesis \& Diškus, 1996: 188, 189, Figs. 25-27.

Generic placement. The re-examination of the male genitalia of the former holotype of Bucculatrix macrognathos (Figs. 7-16, 19, 20, 24-29), along with a study of previously unknown female, revealed that this species fitted ideally the generic concept of Aristotelia Hübner. Therefore, B. macrognathos has been transferred to Aristotelia, Gelechiidae.

Diagnosis. Externally, Aristotelia macrognathos can be distinguished by a combination of 
a small size of an adult and bright and contrasting forewing with a costal margin suffused with brown, three yellowish brown irregular patches centrally separated by white stripes. In the male genitalia, A. macrognathos differs from other representatives of Aristotelia by the wide, trian- gular sacculus with a serrated ventral margin; in the female genitalia, by the elongated signum with distinctive lateral spines.

Description. It is a medium small moth: forewing length $2.8-3.2 \mathrm{~mm}$, wingspan $6.1-$ $7.0 \mathrm{~mm}$ (Figs. 1-3).

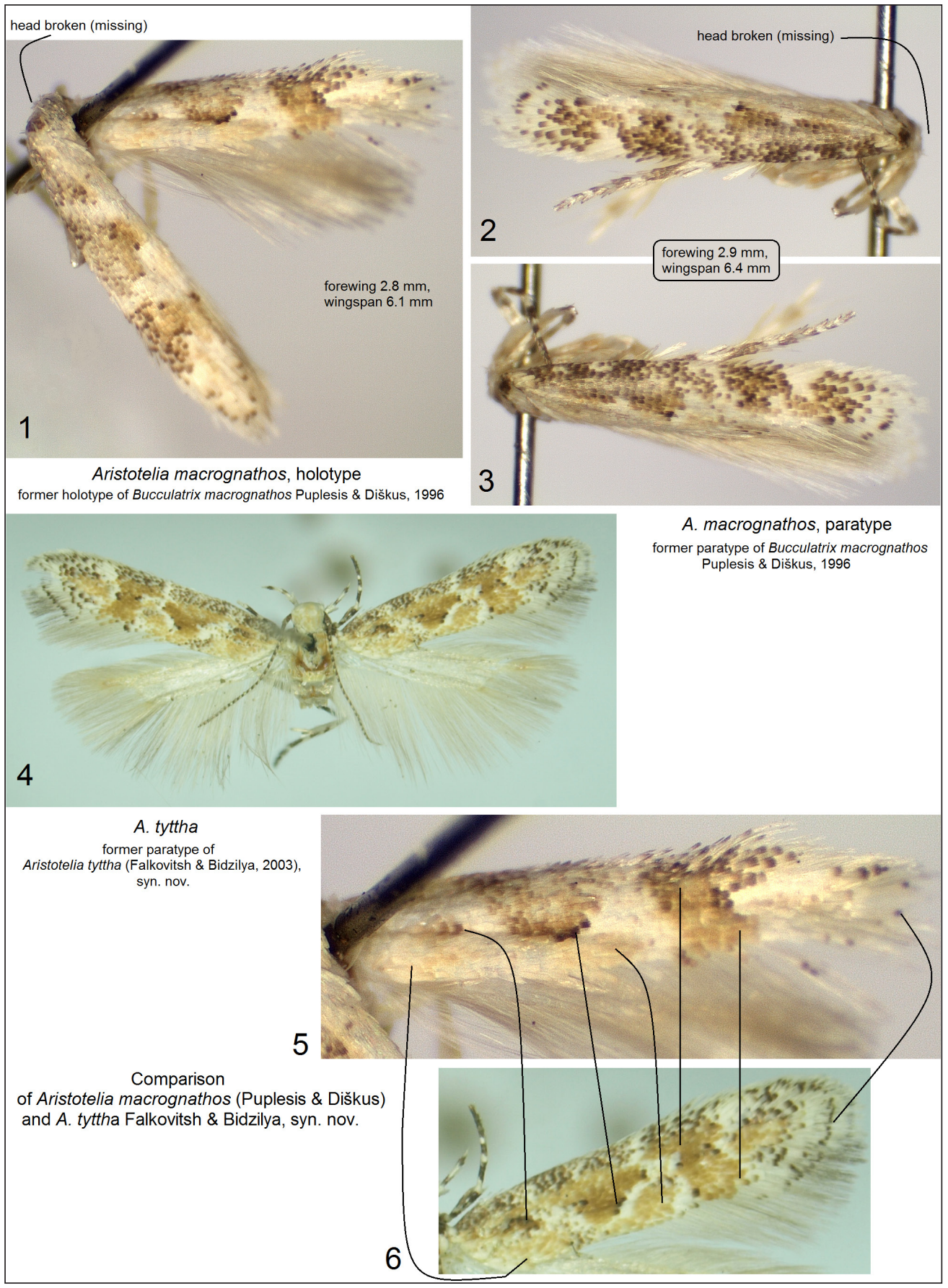

Figs. 1-6. Photographic documentation and comparison of the forewing pattern of Aristotelia macrognathos (Puplesis \& Diškus, 1996) (comb. nov.) and A. tyttha Falkovitsh \& Bidzilya, 2003 (syn. nov.) 
Male genitalia (Figs. 7-16, 19, 20, 24-27): $\mu \mathrm{m}$ long, basally 105-110 $\mu \mathrm{m}$ wide. For capsule 300-305 $\mu \mathrm{m}$ long; tegumen $155 \mu \mathrm{m}$ wide; valva $230-235 \mu \mathrm{m}$ long; phallus 250 a primary description, see Puplesis, Diškus (1996).

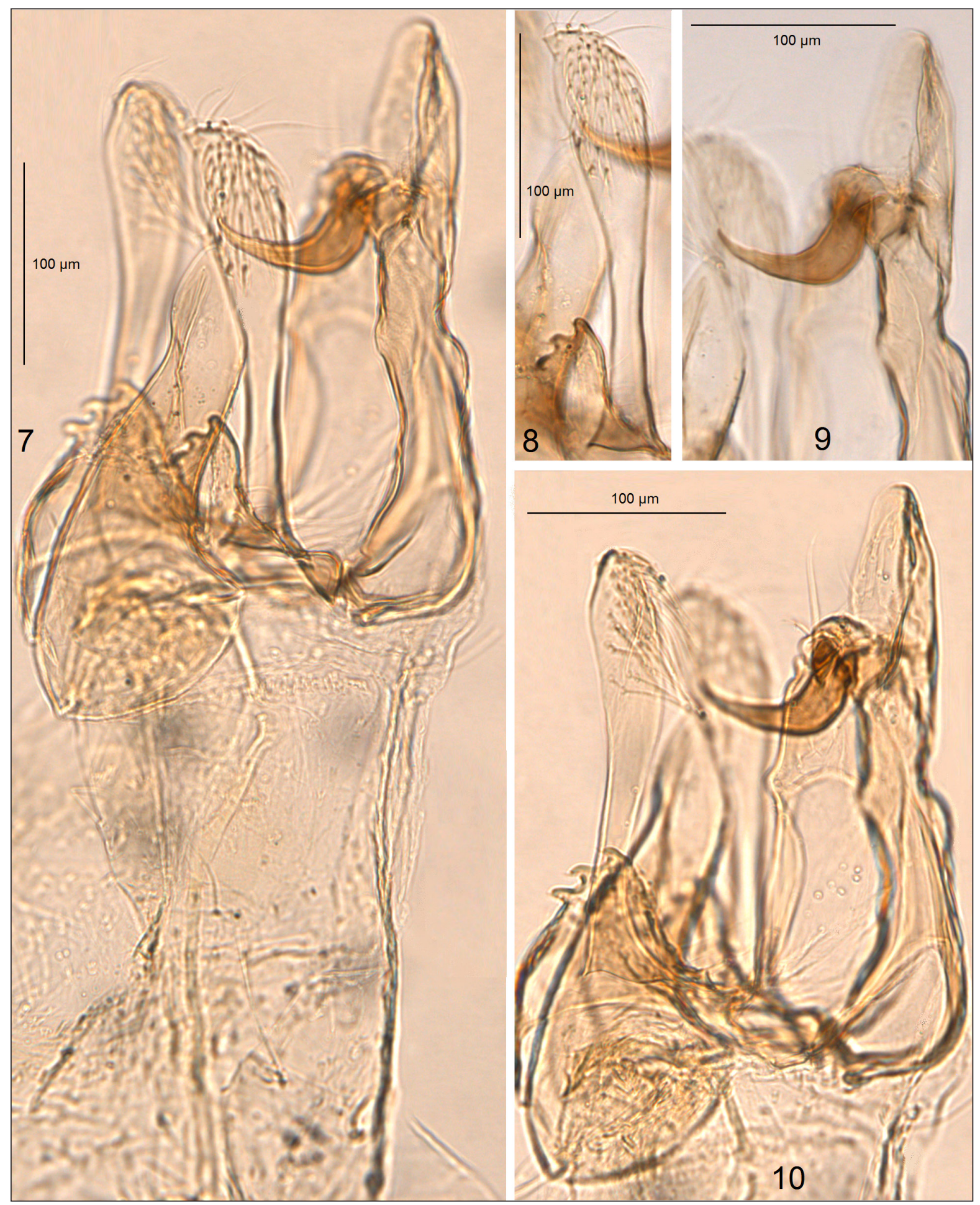

Figs. 7-10. The first photographic documentation of male genitalia of the holotype of Aristotelia macrognathos (Puplesis \& Diškus, 1996) (comb. nov.), genitalia slide no. AD1035 (ZIN) 


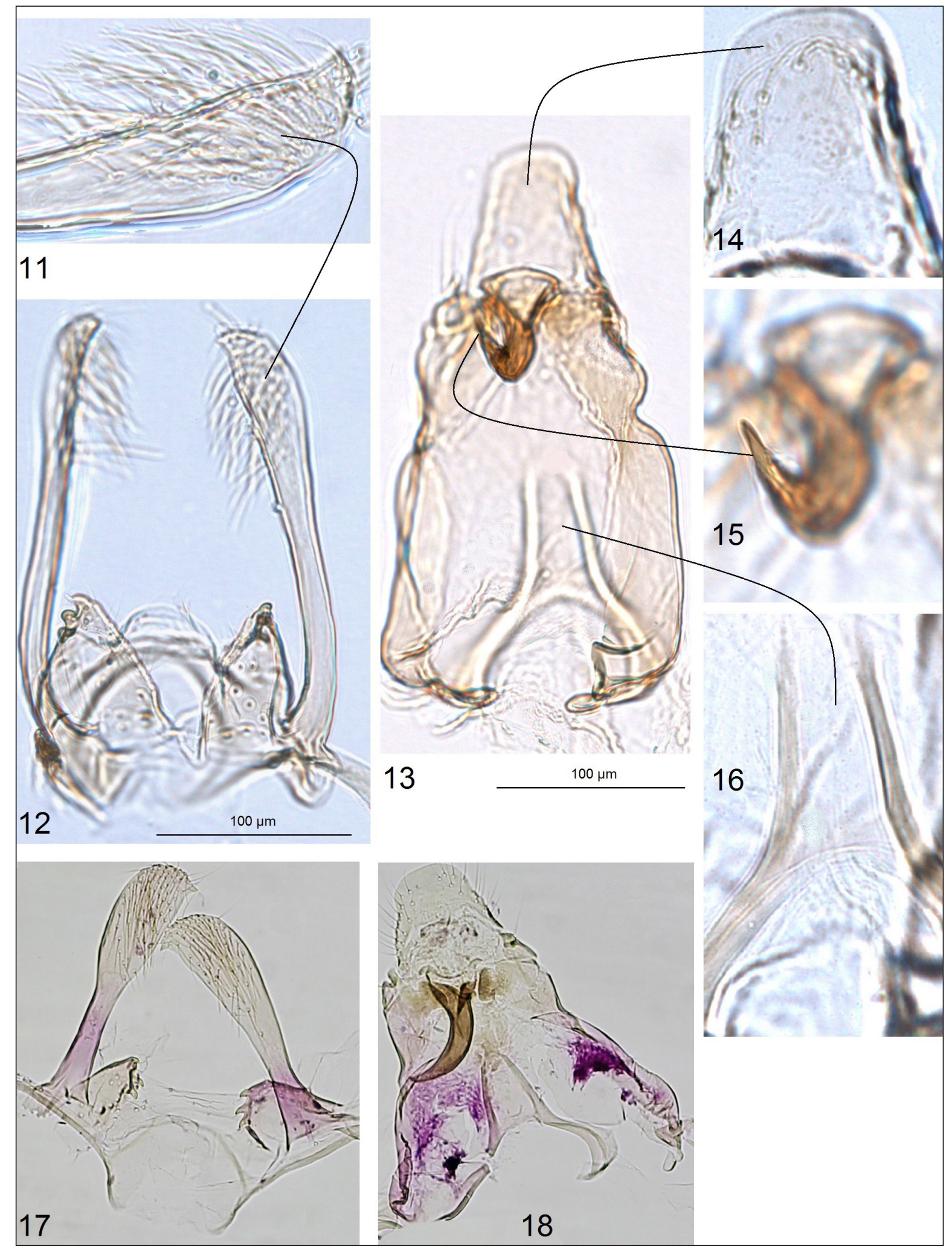

Figs. 11-18. The first photographic documentation and comparison of the male genitalia of Aristotelia macrognathos (Puplesis \& Diškus, 1996) (comb. nov.) and A. tyttha Falkovitsh \& Bidzilya, 2003 (syn. nov.): 11-16 - holotype of A. macrognathos, genitalia slide no. AD1035 (ZIN); 17, 18 - paratype of A. tyttha, genitalia slide no. 55/07 O. Bidzilya (ZIN) 


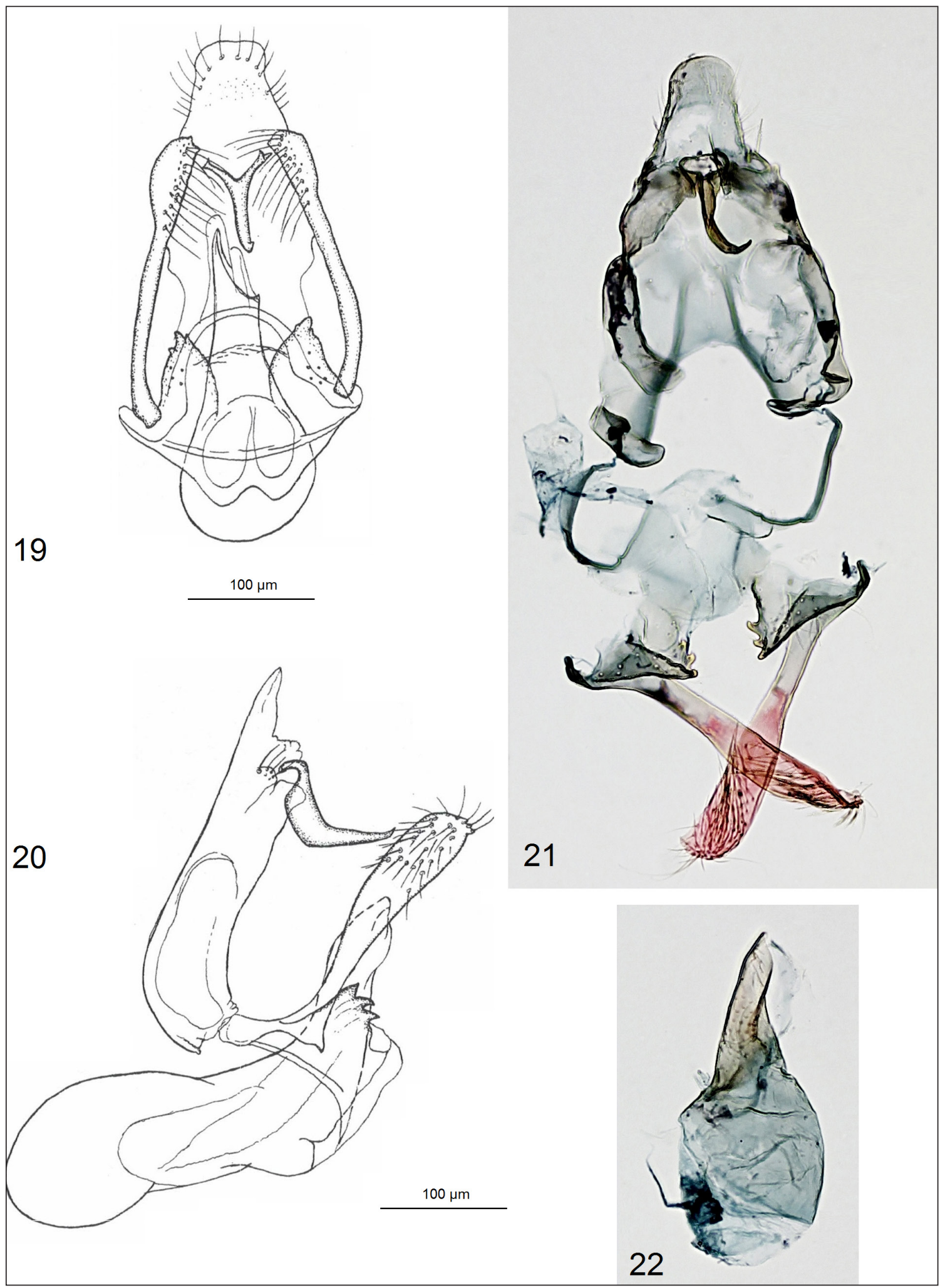

Figs. 19-22. Comparison of the male genitalia of Aristotelia macrognathos (Puplesis \& Diškus, 1996) (comb. nov.) and A. tyttha Falkovitsh \& Bidzilya, 2003 (syn. nov.): 19, 20 - holotype of A. macrognathos (after Puplesis and Diškus, 1996); 21, 22 - paratype of A. tyttha, genitalia slide no. 194/20, O. Bidzilya (ZMKU) 


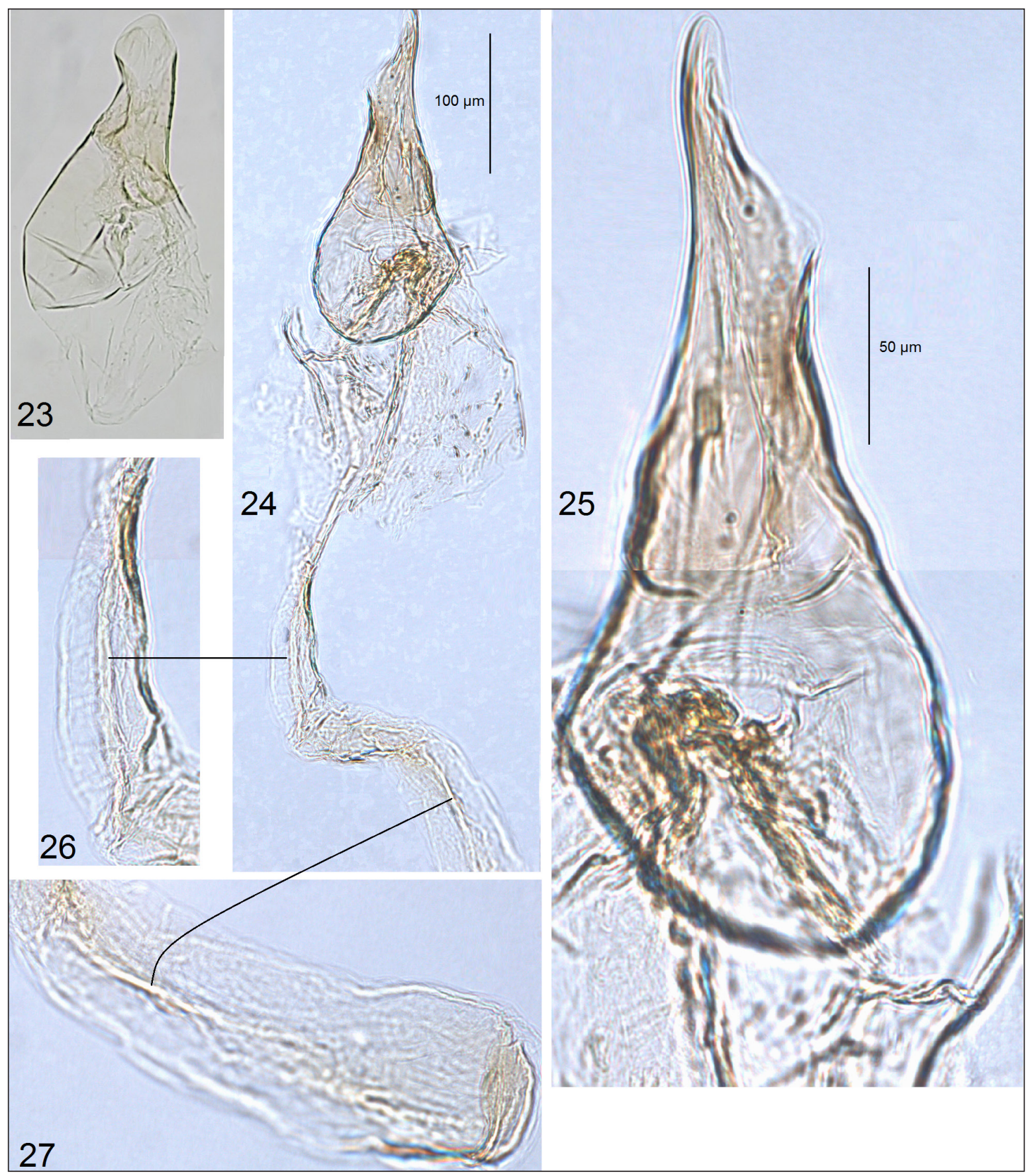

Figs. 23-27. The first photographic documentation and comparison of phallus of Aristotelia macrognathos (Puplesis \& Diškus, 1996) (comb. nov.) and A. tyttha Falkovitsh \& Bidzilya, 2003 (syn. nov.): 23 - A. tyttha, genitalia slide no. 55/07 O. Bidzilya (ZIN); 24-27 - holotype of A. macrognathos, genitalia slide no. AD1035 (ZIN)

Female genitalia (Figs. 28, 29). Papillae anales subovate, densely covered with hair-like setae; apophyses posteriores straight, slender, about 1.5 times as long as papillae anales and twice as long as apophyses anteriores. Sternum VIII with a narrow postmedial emargination widened anteriorly, plainly sclerotised, unmodified except for a medial fold terminated into short pointed tips, anterior margin sclerotised and weakly bent; ductus bursae of moderate width, weakly 


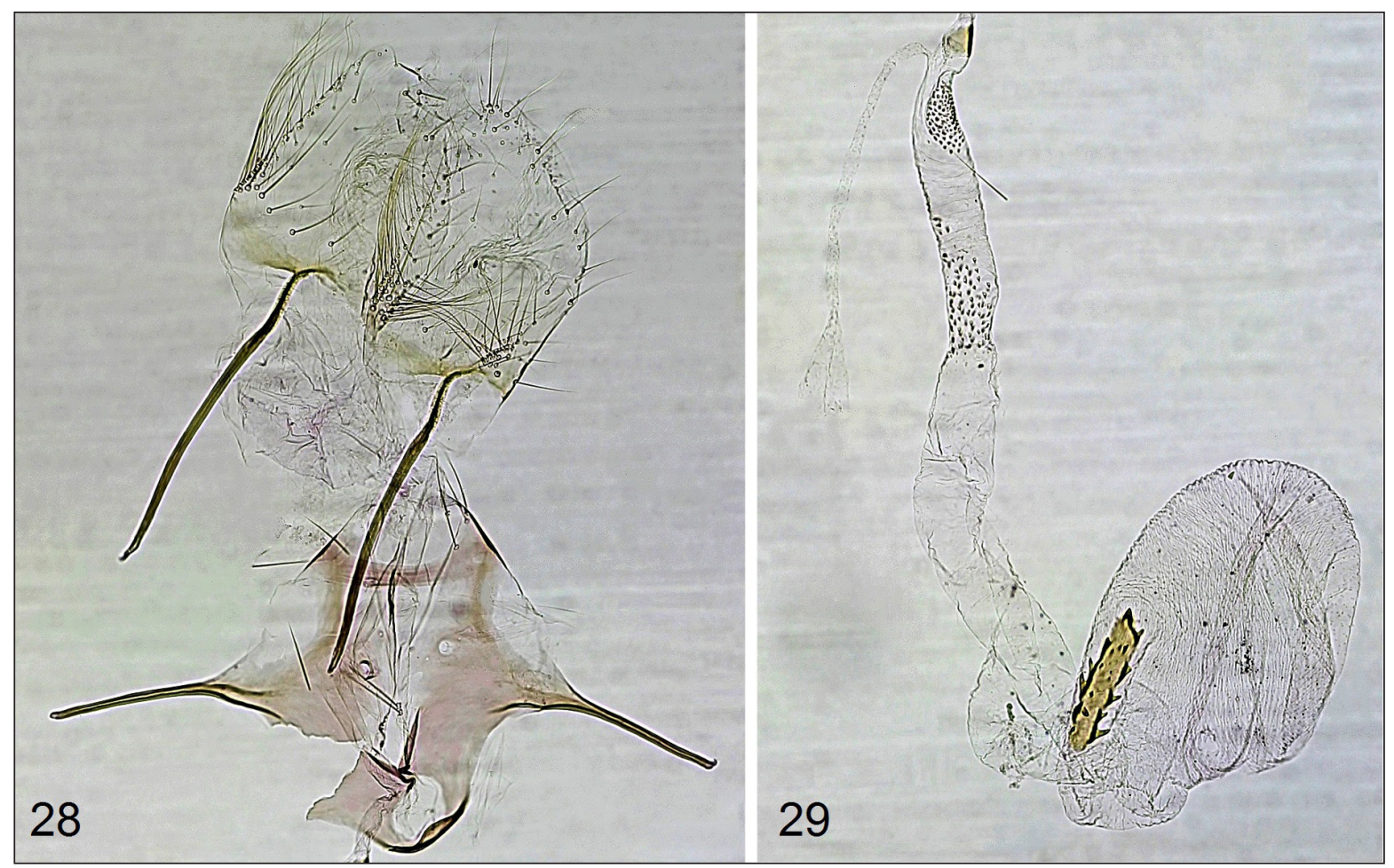

Figs. 28, 29. The first photographic documentation of the female genitalia of Aristotelia macrognathos $(\mathrm{Pu}-$ plesis \& Diškus, 1996) (comb. nov.), genitalia slide no. 55/07 O. Bidzilya (ZMKU): 28 - papillae anales and apophyses; 29 - bursae copulatrix

widened near the entrance of corpus bursae, colliculum slender, band-shaped; ductus seminalis arises from about $1 / 8$ length of ductus bursae; bursae copulatrix egg-shaped; signum elongated, with distinct lateral spines, about $1 / 3$ length of corpus bursae.

Material examined. $1 \lesssim$ (holotype, without a head), eastern TURKMENISTAN, env. of Svintsovyy Rudnik (Kugitangtau ridge), 11.viii.1989, leg. V. Sruoga, genitalia slide no. AD1035 (ZIN). $1 \hat{\delta}$ (paratype, without a head, abdomen missing), same locality, 26.viii.1990, leg. R. Puplesis (ZIN). 1 (paratype of $A$. tyttha), UZBEKISTAN, Ajakguzhumdy, $40 \mathrm{~km}$ of Dzhyngildy, 7.vi.1967, ex larva feeding on Atraphaxis spinosa, leg. M. Falkovitsh, genitalia slide no. 194/20,

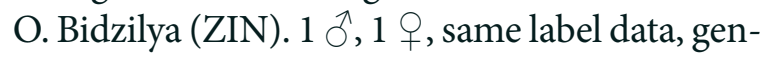
italia slide no. 55/07ðึ , O. Bidzilya (ZMKU).

Remarks. Here, we provide the first photographic documentation of $A$. macrognathos: Figs. 1-6 (forewing pattern), Figs. 7-18, 21-27 (male genitalia), and Figs. 28, 29 (female genitalia).

\section{COMPARISON OF ARISTOTELIA MACROGNATHOS AND A. TYTTHA, SYN. NOV.}

The examination and comparison of the forewing pattern of the holotype and paratype of Aristotelia macrognathos (Figs. 1-3), male paratype (Fig. 4), and two additional, non-type specimens of both sexes of $A$. tyttha revealed close similarity, and only a few differences were found among the studied specimens. The differences are insignificant and could be considered to be a result of an individual or geographical variation between the specimens collected in eastern Turkmenistan (A. macrognathos) and adjacent Uzbekistan (A. tyttha).

The examination and comparison of male genitalia of the holotype of $A$. macrognathos with one paratype and one non-type male specimen of $A$. tyttha (Figs. 7-27) showed no significant differences between the studied specimens. Since the gnathos is movable, 
it may look different due to the angle of view or the slide mount (Figs. 9, 13, 15). In general, we found that gnathos of $A$. macrognathos (Fig. 19) and A. tyttha (Figs. 18, 21) were almost identical. The differences in the phallus between A. macrognathos (Figs. 19, 20, 24-27) and A. tyttha (Figs. 22, 23) could have occurred due to the preparation of the slides. Otherwise, the structures of the male genitalia of A. macrognathos and A. tyttha are identical.

\section{CONCLUSIONS}

1. On the basis of the re-examination of typeseries specimens, the former Bucculatrix macrognathos Puplesis \& Diškus, 1996, has been excluded from Bucculatricidae and transferred to Gelechiidae, and now it should be treated as Aristotelia macrognathos (Puplesis \& Diškus), comb. nov.

2. On the basis of the comparison of the forewing pattern and male genitalia, A. tyttha Falkovitsh \& Bidzilya, 2003, has been synonymised with $A$. macrognathos (Puplesis \& Diškus, 1996), with the holotype and paratype deposited at ZIN.

3. The female genitalia of $A$. macrognathos were described for the first time and characterised by the elongated signum with distinctive lateral spines.

4. The host plant of A. macrognathos is Atraphaxis spinosa L. (Polygonaceae) because this plant was earlier recorded as the host of the currently synonymised A. tyttha.

\section{ACKNOWLEDGEMENTS}

Jonas Rimantas Stonis thanks Arūnas Diškus for his generous help in preparing a permanent slide of the holotype of the former Bucculatrix macrognathos (slide no. AD1035) and for his contribution to the list of references.

This research was partially funded by a grant (S-MIP-19-30, 'DiagnoStics') from the Research Council of Lithuania.

The first author carried out his part of the study within the framework of the implementation of the State Budget Programme 'Support for the Development of Priority Areas of Scientific Research', Ukraine (Code: 6541230).

Received 20 March 2021

Accepted 9 April 2021

\section{References}

1. Becker VO. 29. Gelechiidae. In: Heppner JB, editor. Atlas of Neotropical Lepidoptera. Checklist: Part 1. The Hague: Dr W. Junk Publishers; 1984. p. 44-53.

2. Bidzilya OV, Budashkin YI. New species of Gelechiidae (Lepidoptera) from Ukraine. Zootaxa. 2015; 2374(2): 217-30.

3. Bidzilya OV, Budashkin YI, Zhakov AV. Check-list of scythridid moths (Lepidoptera, Scythrididae) of Ukraine with description of two new species. Zootaxa. 2017; 4291(3): 481-503.

4. Falkovitsh MI, Bidzilya OV. Gelechiidae (Lepidoptera) reared from the larvae collected in Kyzylkum desert, with descriptions of new species. Proc Zool Mus Kiev Taras Shevchenko Natl Univ. 2003; 1: 113-47.

5. Lee S, Hodges RW, Brown RL. Checklist of Gelechiidae (Lepidoptera) in America North of Mexico. Zootaxa. 2009; 2231: 1-39.

6. Puplesis R, Diškus A. Five new mining Lepidoptera (Nepticulidae, Bucculatricidae) from Central Asia. Tijdschr Entomol. 1996; 139(2): 181-90.

7. Puplesis R, Diškus A. The Nepticuloidea \& Tischerioidea (Lepidoptera) - a global review, with strategic regional revisions. Kaunas: Lutute Publishers; 2003. 512 p.

8. Puplesis R, Seksjaeva S, Puplesienè J. Bucculatrix formosa sp. n., a remarkable species from the Kugitangtau Mountains (Central Asia) (Lepidoptera: Bucculatricidae). Nota lepidopterol. 1992; 15(1): 41-6.

9. Stonis JR, Diškus A, Remeikis A, Navickaitè A. Study methods of Nepticulidae: micro-mounts of genitalia structures. In: Stonis JR, Hill SR, 
Diškus A, Auškalnis T, editors. Selected abstracts and papers of the First Baltic International Conference on Field Entomology and Faunistics. Vilnius: Edukologija Publishers; 2014. p. 32-35.

10. Vári L, Kroon D, Krüger M. Classification and checklist of the species of Lepidoptera recorded in southern Africa. Australia: Chatswood; 2002. $384 \mathrm{p}$.
Oleksiy Bidzilya, Jonas Rimantas Stonis

CENTRINĖS AZIJOS BUCCULATRIX MACRO-

GNATHOS PERKELTA I ARISTOTELIA, GELE-

CHIIDAE, O A. TYTTHA TAPO A. MACRO-

GNATHOS JAUNESNIUOJU SINONIMU

\section{Santrauka}

Pakartotinai ištyrus tipinę seriją, Bucculatrix macrognathos Puplesis \& Diškus, 1996 buvo perkelta iš Bucculatricidae šeimos $\mathfrak{i}$ Gelechiidae. Aristotelia tyttha Falkovitsh \& Bidzilya, 2003 tapo A. macrognathos jaunesniuoju sinonimu, o Astrophaxis spinosa L. (Polygonaceae) - A. macrognathos mitybiniu augalu, nes šis augalas anksčiau buvo nurodytas kaip šiuo metu sinonimizuotos $A$. tyttha mitybinis augalas. Straipsnyje pirmą kartą aprašytos anksčiau nežinomos $A$. macrognathos patelès genitalinès struktūros ir pirmą kartą pateiktos A. macrognathos patino genitalinių struktūrų nuotraukos.

Raktažodžiai: Atraphaxis spinosa, Bucculatricidae, nauja taksonominé kombinacija, naujas sinonimas, patino ir pateles genitalijos 